\title{
Associations of Helicobacter pylori infection and chronic atrophic gastritis with accelerated epigenetic ageing in older adults
}

\author{
Xu Gao ${ }^{1}$, Yan Zhang ${ }^{1}$ and Hermann Brenner ${ }^{\star}, 1,2,3$ \\ ${ }^{1}$ Division of Clinical Epidemiology and Aging Research, German Cancer Research Center (DKFZ), Im Neuenheimer Feld 581, 69120 \\ Heidelberg, Germany; ${ }^{2}$ Division of Preventive Oncology, German Cancer Research Center (DKFZ) and National Center for Tumor \\ Diseases (NCT), Im Neuenheimer Feld 460, 69120 Heidelberg, Germany and ${ }^{3}$ German Cancer Consortium (DKTK), German Cancer \\ Research Center (DKFZ), Im Neuenheimer Feld 280, 69120 Heidelberg, Germany
}

Background: Helicobacter pylori (HP) infection and chronic atrophic gastritis (CAG) have shown strong associations with the development of gastric cancer. This study aimed to examine whether both risk factors are associated with accelerated epigenetic ageing, as determined by the 'DNA methylation age', in a population-based study of older adults $(n=1477)$.

Methods: Serological measurements of HP antibodies and pepsinogen I and II for CAG definition were obtained by ELISA kits. Whole blood DNA methylation profiles were measured by Illumina Human Methylation450K Beadchip. DNA methylation ages were calculated by two algorithms proposed by Horvath and Hannum et al.

Results: After adjusting for potential covariates in linear regression models, we found that HP infection, infection with virulent HP strains $(\mathrm{CagA}+)$ and severe CAG were significantly associated with an increase in DNA methylation age by $\sim 0.4,0.6$ and 1 year (all $P$-values $<0.05$ ), respectively.

Conclusions: Our study indicates that both CagA + HP infection and CAG go along with accelerated epigenetic ageing.

Gastric cancer is the third leading cause of cancer mortality globally (Ferlay et al, 2015). Helicobacter pylori (HP) is related aetiologically to gastric cancer by playing a key role in the development of gastric carcinogenesis (Graham, 2015). HP infection also shows a causal relationship with chronic atrophic gastritis (CAG), a chronic, strongly age-related condition, which is a critical precursor lesion of gastric cancer (Weck and Brenner, 2008) and related to other chronic, age-related health outcomes, such as vitamin $\mathrm{B}_{12}$ deficiency and cardiovascular disease (CVD) (Lewerin et al, 2008; Franceschi et al, 2009). Previous studies have shown that HP infection is closely related to DNA methylation changes in gastric mucosa and whole blood samples (Maekita et al, 2006; Zhang et al, 2016). One of the conceivable causes is that the oxidative stress induced by HP infection contributes to the accelerated senescence of cells and ageing (Naito and Yoshikawa, 2002; Pandey and Rizvi, 2010). Moreover, based on the age-related alterations of DNA methylation, researchers have established the concept of DNA methylation age (Hannum et al, 2013; Horvath, 2013), and have employed the discrepancy between DNA methylation age and chronological age (termed 'age acceleration'(AA)) as an informative biomarker of ageing and ageing-related health outcomes. Given the associations of HP infection with ageing and DNA methylation alterations, it would appear plausible that HP infection might have an impact on the disproportional agieng reflected by DNA methylation age. To investigate this hypothesis, we explored the associations of both HP infection and CAG with AA in a large population-based study of older adults (ESTHER) in Germany.

*Correspondence: Dr H Brenner; E-mail: h.brenner@dkfz-heidelberg.de

Received 31 May 2017; revised 3 August 2017; accepted 18 August 2017; published online 12 September 2017

(C) 2017 Cancer Research UK. All rights reserved 0007-0920/17 


\section{MATERIALS AND METHODS}

The methods for this study are described in detail in Supplementary Material. Briefly, we selected 1509 older adults (aged 50-75 years) enroled in the ESTHER study between July 2000 and March 2001 and collected their socio-demographic characteristics, lifestyle factors and health status by standardised questionnaires (Supplementary Figure 1) (Gao et al, 2016a). Participants were categorised into three groups according to the serostatus of immunoglobulin $\mathrm{G}(\mathrm{IgG})$ antibodies and antibodies specific to the cytotoxin-associated gene A ( $\mathrm{CagA})$ : infected by less virulent strains $(\operatorname{IgG}+/ \mathrm{CagA}-)$, infected by virulent strains $(\mathrm{IgG}+/ \mathrm{CagA}+)$ and non-infected (IgG-/CagA-) (Chen et al, 2016). We excluded 32 participants with IgG-/CagA + HP, which often reflects past infection. Serum concentrations of pepsinogen (PG) I and II were measured as biomarkers of CAG, and we used the following commonly employed serological classification to define CAG: PG I $<70 \mathrm{ng} \mathrm{ml}^{-1}$ and PG I/II ratio $<3.0$. Blood DNA methylation was quantified by Illumina $450 \mathrm{~K}$ chip and the DNA methylation age of each participant was calculated by the algorithms of Horvath and Hannum et al (Hannum et al, 2013; Horvath, 2013). AAs were determined as the residuals calculated by the linear regression models of both forms of epigenetic age on chronological age (Gao et al, 2016b).

\section{RESULTS}

Table 1 summarises characteristics of the 1477 eligible participants. Average chronological age was $\sim 62$ years. Hannum et al methylation ages were higher than chronological age and age computed by Horvath's approach. Both forms of DNA methylation age and chronological age were highly correlated with each other (Supplementary Figure 2). The prevalence of any HP and CagA + HP infection was $51.8 \%$ and $26.7 \%$, respectively, and around $12 \%$ participants had CAG (mild or severe). HP infection status and serostatus were significantly associated with both AAs (Table 2; $P$-values $<0.05)$. Participants infected with virulent strains $(\mathrm{CagA}+)$ had the highest AAs, followed by those infected with less virulent strains (CagA-). Similarly, both AAs demonstrated positive correlations with the CAG status and severity of CAG, which was though statistically significant only for the AA based on the algorithm by Hannum et al (Table 2; $P$-values $=0.015 / 0.024$ ).

We further examined the associations of AAs (outcomes) with HP infection status or CAG severity (independent variables) by three linear regression models, increasingly controlling for potential covariates. HP infection, infection with CagA + strains and severe CAG were significantly associated with both AAs after adjustment for age, sex and the leucocyte distribution (Table 3; all $P$-values $<0.05)$. Although in the fully adjusted model, associations of the AA according to Horvath's algorithm with HP infection/severe CAG were slightly attenuated $(P$-values $=0.05)$, additional adjustment for other covariates did not alter the patterns in any relevant manner. However, CAG (yes/no) was only associated with the AA according to Hannum's algorithm, but not the AA according to Horvath's algorithm. This pattern remained essentially unchanged in the sensitivity analysis in which we adjusted for both HP infection status and the CAG status simultaneously ( $P$-value of CAG for $\mathrm{AA}_{\text {Horvath }}=0.118 ; P$-value of CAG for $\left.\mathrm{AA}_{\text {Hannum }}=0.012\right)$. Overall, we observed that $\mathrm{HP}$ infection, infection of $\mathrm{CagA}+$ strains and severe CAG were associated with the DNA methylation-defined AA. In the fully adjusted model, these risk factors were associated with an increase in DNA methylation age by $\sim 0.4,0.6$ and 1 year, respectively.
Table 1. Population characteristics of ESTHER study

\begin{tabular}{|c|c|}
\hline \multicolumn{2}{|l|}{ Characteristic } \\
\hline$N$ & 1477 \\
\hline Age (years) & $62.0(6.5)$ \\
\hline Methylation age 1 (Horvath, years) & $62.2(7.3)$ \\
\hline Methylation age 2 (Hannum, years) & $68.2(7.1)$ \\
\hline Gender (male) & 495 (50.6\%) \\
\hline $\begin{array}{l}\text { HP serostatus } \\
\lg \text { - }-/ \text { CagA- } \\
\lg \text { + / CagA- } \\
\lg \mathrm{I}+/ \text { CagA }+\end{array}$ & $\begin{array}{l}712(48.2 \%) \\
371(25.1 \%) \\
394(26.7 \%)\end{array}$ \\
\hline $\begin{array}{l}\text { Severity of } \mathrm{CAG}^{\mathbf{b}} \\
\text { Non-atrophic } \\
\text { Mild atrophic } \\
\text { Severe atrophic }\end{array}$ & $\begin{array}{c}1304 \text { (88.3\%) } \\
75 \text { (5.1\%) } \\
98(6.6 \%)\end{array}$ \\
\hline $\begin{array}{l}\text { Smoking status } \\
\text { Current smoker } \\
\text { Former smoker } \\
\text { Never smoker }\end{array}$ & $\begin{array}{l}276(18.7 \%) \\
499(33.8 \%) \\
702(47.5 \%)\end{array}$ \\
\hline $\begin{array}{l}\text { Body mass index }{ }^{c} \\
\text { Underweight or normal weight }(<25.0) \\
\text { Overweight }(25 \text { to }<30) \\
\text { Obese }(\geqslant 30.0)\end{array}$ & $\begin{array}{l}399(27.1 \%) \\
685(46.5 \%) \\
390(26.5 \%)\end{array}$ \\
\hline $\begin{array}{l}\text { Alcohol consumption }^{\text {d }} \\
\text { Abstainer } \\
\text { Low } \\
\text { Intermediate } \\
\text { High }\end{array}$ & $\begin{array}{c}471(34.3 \%) \\
804(58.5 \%) \\
78(5.7 \%) \\
21(1.5 \%)\end{array}$ \\
\hline $\begin{array}{l}\text { Physical activity } \\
\text { Inactive } \\
\text { Low } \\
\text { Medium or high }\end{array}$ & $\begin{array}{l}294(19.9 \%) \\
673(45.6 \%) \\
510(34.5 \%)\end{array}$ \\
\hline $\begin{array}{l}\text { Education }{ }^{f} \\
\leqslant 9 \text { years } \\
10-11 \text { years } \\
\geqslant 12 \text { years }\end{array}$ & $\begin{array}{r}1071(74.1 \%) \\
224(15.5 \%) \\
150(10.4 \%)\end{array}$ \\
\hline Prevalence of CVD' (yes) & 265 (17.9\%) \\
\hline Prevalence of diabetes ${ }^{\mathbf{h}}$ (yes) & $230(15.7 \%)$ \\
\hline Prevalence of cancer (yes) & $88(6.0 \%)$ \\
\hline 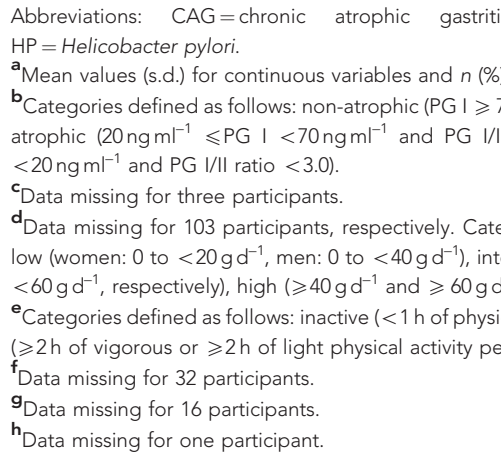 & $\begin{array}{l}\text { ardiovascular disease; } \\
\text { cal variables. } \\
\text { PG I/II ratio } \geqslant 3.0 \text { ), mild } \\
\text { severe atrophic (PG I } \\
\text { d as follows: abstainer, } \\
\text { to }<40 \mathrm{~g} \mathrm{~d}^{-1} \text { and } 40 \text { to } \\
\text { ly). } \\
\text { rweek), medium or high } \\
\text { (other). }\end{array}$ \\
\hline
\end{tabular}

\section{DISCUSSION}

In summary, we found HP infection, in particular, infection with CagA + HP strains, to be associated with accelerated ageing. The underlying mechanisms are not yet to be elaborated by further research. A plausible pathological mechanism might be the oxidative damage triggered by the reactive oxygen species that resulted from the inflammation induced by the HP infection (Farinati et al, 2008). The damage caused by oxidative stress has been commonly recognised as a contributor to the functional decline related to ageing (Hekimi et al, 2011) and has been found 
Table 2. Distributions of age accelerations based on Helicobacter pylori (HP) infection and severity of chronic atrophic gastritis (CAG)

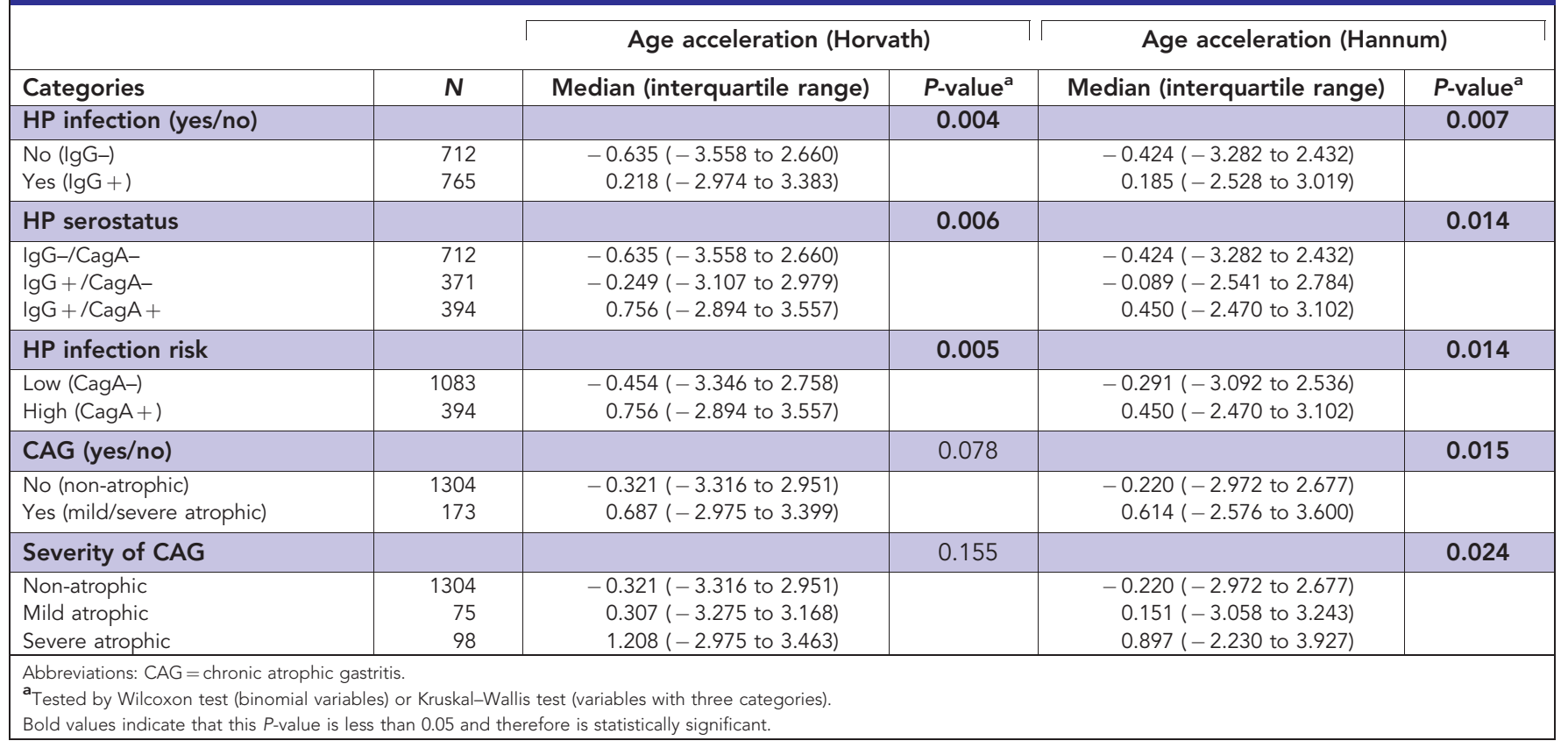

Table 3. Associations of Helicobacter pylori (HP) infection and severity of chronic atrophic gastritis (CAG) with age acceleration

\begin{tabular}{|c|c|c|c|c|c|c|c|c|c|c|c|c|c|}
\hline \multirow[b]{3}{*}{ Categories } & \multirow[b]{3}{*}{$N$} & \multicolumn{6}{|c|}{ Age acceleration (Horvath) } & \multicolumn{6}{|c|}{ Age acceleration (Hannum) } \\
\hline & & \multicolumn{2}{|c|}{ Model $1^{a}$} & \multicolumn{2}{|c|}{ Model $2^{b}$} & \multicolumn{2}{|c|}{ Model $3^{c}$} & \multicolumn{2}{|c|}{ Model $1^{a}$} & \multicolumn{2}{|c|}{ Model $2^{b}$} & \multicolumn{2}{|c|}{ Model $3^{c}$} \\
\hline & & $\begin{array}{l}\text { Beta } \\
\text { (s.d.) }\end{array}$ & $\begin{array}{c}P- \\
\text { value }\end{array}$ & $\begin{array}{l}\text { Beta } \\
\text { (s.d.) }\end{array}$ & $\begin{array}{c}P- \\
\text { value }\end{array}$ & $\begin{array}{l}\text { Beta } \\
\text { (s.d.) }\end{array}$ & $\begin{array}{c}P- \\
\text { value }\end{array}$ & $\begin{array}{l}\text { Beta } \\
\text { (s.d.) }\end{array}$ & $\begin{array}{c}P- \\
\text { value }\end{array}$ & $\begin{array}{l}\text { Beta } \\
\text { (s.d.) }\end{array}$ & $\begin{array}{c}P- \\
\text { value }\end{array}$ & $\begin{array}{l}\text { Beta } \\
\text { (s.d.) }\end{array}$ & $\begin{array}{c}P \text { - } \\
\text { value }\end{array}$ \\
\hline \multicolumn{14}{|c|}{ HP infection (yes/no) } \\
\hline $\begin{array}{l}\text { No (lgG-) } \\
\text { Yes (IgG +) }\end{array}$ & $\begin{array}{l}712 \\
765\end{array}$ & \begin{tabular}{c|} 
Ref \\
$0.613(0.242)$
\end{tabular} & 0.011 & \begin{tabular}{c|} 
Ref \\
$0.376(0.254)$
\end{tabular} & 0.049 & \begin{tabular}{|c|} 
Ref \\
$0.366(0.255)$
\end{tabular} & 0.050 & \begin{tabular}{c|} 
Ref \\
$0.538(0.209)$
\end{tabular} & 0.010 & \begin{tabular}{c|} 
Ref \\
$0.432(0.217)$
\end{tabular} & 0.026 & \begin{tabular}{|c|} 
Ref \\
$0.450(0.218)$ \\
\end{tabular} & 0.039 \\
\hline \multicolumn{14}{|l|}{ HP serostatus } \\
\hline $\begin{array}{l}\operatorname{lgG}-/ \text { CagA- } \\
\operatorname{lgG}+/ \text { CagA- } \\
\operatorname{lgG}+/ \text { CagA }+\end{array}$ & $\begin{array}{l}712 \\
371 \\
394\end{array}$ & \begin{tabular}{c|} 
Ref \\
$0.411(0.297)$ \\
$0.803(0.290)$
\end{tabular} & $\begin{array}{l}0.166 \\
0.006\end{array}$ & \begin{tabular}{c|} 
Ref \\
$0.371(0.312)$ \\
$0.697(0.307)$
\end{tabular} & $\begin{array}{l}0.906 \\
0.023\end{array}$ & \begin{tabular}{c|} 
Ref \\
$0.063(0.313)$ \\
$0.652(0.307)$
\end{tabular} & $\begin{array}{l}0.841 \\
0.034\end{array}$ & \begin{tabular}{c|} 
Ref \\
$0.399(0.256)$ \\
$0.668(0.251)$
\end{tabular} & $\begin{array}{l}0.119 \\
0.008\end{array}$ & \begin{tabular}{c|} 
Ref \\
$0.290(0.267)$ \\
$0.567(0.267)$
\end{tabular} & $\begin{array}{l}0.277 \\
0.031\end{array}$ & \begin{tabular}{|c|} 
Ref \\
$0.312(0.269)$ \\
$0.581(0.263)$ \\
\end{tabular} & $\begin{array}{l}0.246 \\
0.028\end{array}$ \\
\hline \multicolumn{14}{|c|}{ HP infection risk } \\
\hline $\begin{array}{l}\text { Low (CagA-) } \\
\text { High (CagA }+ \text { ) }\end{array}$ & $\begin{array}{c}1083 \\
394\end{array}$ & \begin{tabular}{c|} 
Ref \\
$0.659(0.271)$
\end{tabular} & 0.015 & \begin{tabular}{c|c} 
Ref \\
$0.684(0.288)$
\end{tabular} & 0.018 & \begin{tabular}{|c|} 
Ref \\
$0.631(0.288)$
\end{tabular} & 0.029 & $\begin{array}{c}\text { Ref } \\
0.528(0.234)\end{array}$ & 0.024 & \begin{tabular}{|c|} 
Ref \\
$0.468(0.245)$
\end{tabular} & 0.042 & \begin{tabular}{|c|} 
Ref \\
$0.475(0.247)$
\end{tabular} & 0.045 \\
\hline \multicolumn{14}{|l|}{ CAG (yes/no) } \\
\hline $\begin{array}{l}\text { No (non-atrophic) } \\
\text { Yes (mild/severe } \\
\text { atrophic) }\end{array}$ & $\begin{array}{c}1304 \\
173\end{array}$ & \begin{tabular}{c|} 
Ref \\
$0.648(0.373)$
\end{tabular} & 0.083 & $\begin{array}{c}\text { Ref } \\
0.586(0.390)\end{array}$ & 0.134 & \begin{tabular}{c|} 
Ref \\
$0.637(0.391)$
\end{tabular} & 0.103 & \begin{tabular}{c|} 
Ref \\
$0.847(0.322)$
\end{tabular} & 0.009 & \begin{tabular}{c|} 
Ref \\
$0.790(0.332)$
\end{tabular} & 0.018 & \begin{tabular}{|c|} 
Ref \\
$0.876(0.334)$ \\
\end{tabular} & 0.009 \\
\hline \multicolumn{14}{|l|}{ Severity of CAG } \\
\hline $\begin{array}{l}\text { Non-atrophic } \\
\text { Mild atrophic } \\
\text { Severe atrophic }\end{array}$ & $\begin{array}{c}1304 \\
75 \\
98\end{array}$ & \begin{tabular}{c|} 
Ref \\
$0.150(0.547)$ \\
$1.030(0.483)$
\end{tabular} & $\begin{array}{l}0.784 \\
0.033\end{array}$ & \begin{tabular}{c|} 
Ref \\
$0.123(0.566)$ \\
$1.003(0.508)$
\end{tabular} & $\begin{array}{l}0.828 \\
0.049\end{array}$ & \begin{tabular}{|c|} 
Ref \\
$0.181(0.569)$ \\
$0.994(0.508)$
\end{tabular} & $\begin{array}{l}0.750 \\
0.050\end{array}$ & \begin{tabular}{c|} 
Ref \\
$0.522(0.472)$ \\
$1.095(0.417)$
\end{tabular} & $\begin{array}{l}0.268 \\
0.009\end{array}$ & \begin{tabular}{c|} 
Ref \\
$0.517(0.482)$ \\
$1.064(0.433)$
\end{tabular} & $\begin{array}{l}0.284 \\
0.014\end{array}$ & \begin{tabular}{|c|} 
Ref \\
$0.637(0.487)$ \\
$1.063(0.434)$ \\
\end{tabular} & $\begin{array}{l}0.191 \\
0.015\end{array}$ \\
\hline \multicolumn{14}{|c|}{ 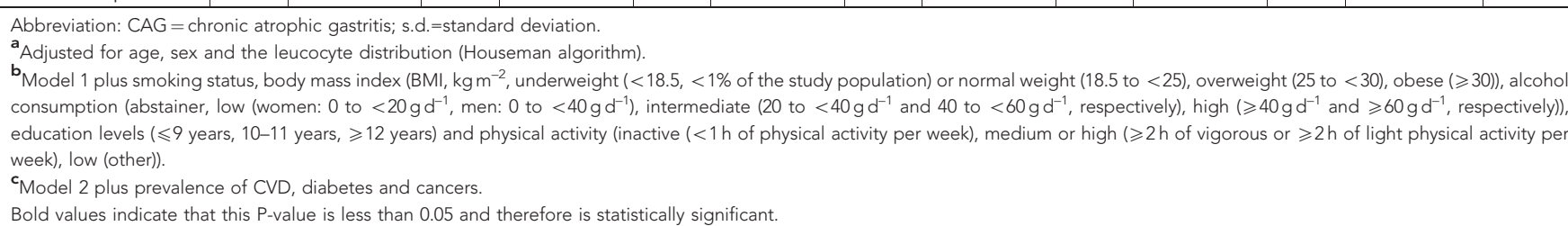 } \\
\hline
\end{tabular}

to be associated with ageing-related DNA methylation changes in whole blood samples (Gao et al, 2017).

Although we controlled for a large number of potential confounders in multivariate analyses, a causal relationship cannot be derived from this cross-sectional epidemiological study. Nevertheless, a causal relationship appears to be plausible due to a variety of reasons. First, HP infection is typically acquired in early childhood (Zhang et al, 2012), a period during which the foundation of age acceleration seems to be laid (Simpkin et al, 2016), and clearly precedes the pattern of age acceleration observed among older adults in our study, despite its cross-sectional design. Second, both HP infection and CAG have been associated with a number of age-related chronic diseases, including but not restricted to gastric cancer, such as CVD and extra-gastric diseases (e.g., 
colonic and pancreatic cancer; Franceschi et al, 2009; Chen et al, 2016). Further research should address the association between HP infection and DNA methylation age at various ages across the lifespan, ideally in a large cohort study in which temporal relationship between the occurrence of $\mathrm{HP}$ infection and AA could be established by repeated measurements of both factors. Another question of major scientific interest and potential major public health relevance might be to what extent AA associated with CagA + HP infection could be reversible after HP eradication.

\section{ACKNOWLEDGEMENTS}

The ESTHER study was supported in part by the BadenWürttemberg state Ministry of Science, Research and Arts (Stuttgart, Germany) and the German Federal Ministry of Education and Research (Berlin, Germany). The work of Xu Gao is supported by the grant from the China Scholarship Council (CSC). The authors gratefully acknowledge contributions of DKFZ Genomics and Proteomics Core Facility, especially Dr Melanie Bewerunge-Hudler and Dr Matthias Schick, in the processing of DNA samples and performing the laboratory work, Dr Jonathan Heiss for providing the estimation of leucocyte distribution and Ms. Chen Chen for the language assistance.

\section{CONFLICT OF INTEREST}

The authors declare no conflict of interest.

\section{REFERENCES}

Chen XZ, Schöttker B, Castro FA, Chen H, Zhang Y, Holleczek B, Brenner H (2016) Association of helicobacter pylori infection and chronic atrophic gastritis with risk of colonic, pancreatic and gastric cancer: a ten-year follow-up of the ESTHER cohort study. Oncotarget 7(13): 17182-17193.

Farinati F, Cardin R, Cassaro M, Bortolami M, Nitti D, Tieppo C, Zaninotto G, Rugge M (2008) Helicobacter pylori, inflammation, oxidative damage and gastric cancer: a morphological, biological and molecular pathway. Eur J Cancer Prev 17(3): 195-200.

Ferlay J, Soerjomataram I, Dikshit R, Eser S, Mathers C, Rebelo M, Parkin DM, Forman D, Bray F (2015) Cancer incidence and mortality worldwide: sources, methods and major patterns in GLOBOCAN 2012. Int J Cancer 136(5): E359-E386.

Franceschi F, Niccoli G, Ferrante G, Gasbarrini A, Baldi A, Candelli M, Feroce F, Saulnier N, Conte M, Roccarina D, Lanza GA, Gasbarrini G, Gentiloni SN, Crea F (2009) CagA antigen of Helicobacter pylori and coronary instability: insight from a clinico-pathological study and a metaanalysis of 4241 cases. Atherosclerosis 202(2): 535-542.

Gao X, Gao X, Zhang Y, Breitling LP, Schottker B, Brenner H (2017) Associations of self-reported smoking, cotinine levels and epigenetic smoking indicators with oxidative stress among older adults: a populationbased study. Eur J Epidemiol 32(5): 443-456.
Gao X, Mons U, Zhang Y, Breitling LP, Brenner H (2016a) DNA methylation changes in response to active smoking exposure are associated with leucocyte telomere length among older adults. Eur J Epidemiol 31(12): 1231-1241.

Gao X, Zhang Y, Breitling LP, Brenner H (2016b) Relationship of tobacco smoking and smoking-related DNA methylation with epigenetic age acceleration. Oncotarget 7(30): 46878-46889.

Graham DY (2015) Helicobacter pylori update: gastric cancer, reliable therapy, and possible benefits. Gastroenterology 148(4): 719-31.e3.

Hannum G, Guinney J, Zhao L, Zhang L, Hughes G, Sadda S, Klotzle B, Bibikova M, Fan JB, Gao Y, Deconde R, Chen M, Rajapakse I, Friend S, Ideker T, Zhang K (2013) Genome-wide methylation profiles reveal quantitative views of human aging rates. Mol Cell 49(2): 359-367.

Hekimi S, Lapointe J, Wen Y (2011) Taking a 'good' look at free radicals in the aging process. Trends Cell Biol 21(10): 569-576.

Horvath S (2013) DNA methylation age of human tissues and cell types. Genome Biol 14(10): R115.

Lewerin C, Jacobsson S, Lindstedt G, Nilsson-Ehle H (2008) Serum biomarkers for atrophic gastritis and antibodies against Helicobacter pylori in the elderly: implications for vitamin B12, folic acid and iron status and response to oral vitamin therapy. Scand J Gastroenterol 43(9): $1050-1056$.

Maekita T, Nakazawa K, Mihara M, Nakajima T, Yanaoka K, Iguchi M, Arii K, Kaneda A, Tsukamoto T, Tatematsu M, Tamura G, Saito D, Sugimura T, Ichinose M, Ushijima T (2006) High levels of aberrant DNA methylation in Helicobacter pylori-infected gastric mucosae and its possible association with gastric cancer risk. Clin Cancer Res 12(3 Pt 1): 989-995.

Naito Y, Yoshikawa T (2002) Molecular and cellular mechanisms involved in Helicobacter pylori-induced inflammation and oxidative stress. Free Radic Biol Med 33(3): 323-336.

Pandey KB, Rizvi SI (2010) Markers of oxidative stress in erythrocytes and plasma during aging in humans. Oxid Med Cell Longev 3(1): 2-12.

Simpkin AJ, Hemani G, Suderman M, Gaunt TR, Lyttleton O, McArdle WL, Ring SM, Sharp GC, Tilling K, Horvath S, Kunze S, Peters A, Waldenberger M, Ward-Caviness C, Nohr EA, Sorensen TI, Relton CL, Smith GD (2016) Prenatal and early life influences on epigenetic age in children: a study of mother-offspring pairs from two cohort studies. Hum Mol Genet 25(1): 191-201.

Weck MN, Brenner H (2008) Association of Helicobacter pylori infection with chronic atrophic gastritis: Meta-analyses according to type of disease definition. Int J Cancer 123(4): 874-881.

Zhang Y, Hoffmeister M, Weck MN, Chang-Claude J, Brenner H (2012) Helicobacter pylori infection and colorectal cancer risk: evidence from a large population-based case-control study in Germany. Am J Epidemiol 175(5): 441-450.

Zhang Y, Zhang XR, Park JL, Kim JH, Zhang L, Ma JL, Liu WD, Deng DJ, You WC, Kim YS, Pan KF (2016) Genome-wide DNA methylation profiles altered by Helicobacter pylori in gastric mucosa and blood leucocyte DNA. Oncotarget 7(24): 37132-37144.

This work is published under the standard license to publish agreement. After 12 months the work will become freely available and the license terms will switch to a Creative Commons AttributionNonCommercial-Share Alike 4.0 Unported License.

Supplementary Information accompanies this paper on British Journal of Cancer website (http://www.nature.com/bjc) 